The

Connecticut

\title{
Globe Artichoke
}

Agricultural

Trials 1998, 2000

Experiment

Station,

Management of Yield

Using Induced or

New Haven

\section{Natural Vernalization}

BY DAVID E. HILL

Bulletin 975 


\section{SUMMARY}

During 1998 and 2000, experiments with globe artichokes were conducted at Mt. Carmel (coastal, loamy, upland soil) to evaluate the yield and quality of newlydeveloped cultivars designed for annual production from seed. Imperial Star, Emerald, and Amethyst are reported to vernalize with relatively short exposure (250 hours) to temperatures below 50F compared to Green Globe and Green Globe Improved, which require longer exposure (500 hours). Imperial Star, Emerald, and Amethyst are thought to vernalize naturally in cool spring temperatures, while Green Globe and Green Globe Improved may require controlled induced vernalization in a refrigerator.

In 1998, Imperial Star with induced vernalization produced 2.4 buds/plant compared to 3.9 buds/plant with natural vernalization. The main stems of plants with natural vernalization were more branching with tertiary buds that developed along the main stem often reaching marketable size. In 2000 , Green Globe produced 5.7 buds/plant followed by Imperial Star with 5.0 buds/plant. Among all cultivars, Emerald had the fewest buds/plant (3.8), but their average weight was greatest ( 6.5 ounces/bud). Average bud weight of Imperial Star and Amethyst also exceeded 6.0 ounces.

Harvest span of Imperial Star with induced vernalization was 15.7 weeks, and 12.8 weeks for plants with natural vernalization. Despite the longer harvest span for plants with induced vernalization, $86 \%$ of the buds were harvested from mid-July to midAugust. In 2000, the harvest span of plants with natural vernalization was 16. I weeks.

For maximum production of Green Globe buds, induced vernalization followed by gibberellic acid treatment in the six-leaf stage may be required. For Imperial Star, Emerald, and Amethyst, natural vernalization in a cold frame without gibberellic acid treatment produced satisfactory yields and eliminated the need for greenhouse space. 


\section{Globe Artichoke Trials 1998, 2000}

\section{Management of Yield Using Induced or Natural Vernalization}

\section{BY DAVID E. HILL}

The globe artichoke (Cynara scolymus) is a thistle-like vegetable that was first enjoyed by Romans centuries before Christ (Splittstoesser 1979). It is a native of the Mediterraneau area grown predominantly in ltaly and France. Spanish and French colonists brought them to America where they flourished in California.

Perennial culture requires cool summers and mild winters. Under these conditions, artichokes grown from root stocks produce continuously for $4-5$ years (Ryder, et al. 1982). When grown from seed, the artichoke plant is a biennial, producing vegetatively the first year and producing edible buds the second year. This two-year cycle requires frost-free winters for survival. In Connecticut, survival of articloke plants during liarsh winters is virtually impossible. The growth cycle, however, can be shortened to 5-6 months by vernalization (cool, moist treatment) of gerninating seed and application of gibberellic acid (GA3) to young plants (Gerakis et al. 1969). I first demonstrated that these teclmiques enable satisfactory production of buds in Connecticut on plants grown as annuals (Hill 1987).

Earlicr attempts at growing artichokes from seed produced plants that were highly variable with buds of inferior quality (Yamaguchi 1983). Recent breeding programs have produced hybrids that are genetically more uniform. Imperial Star was developed for use in Southern Califormia winter vegetable growing areas (Sclirader and Mayberry 1992). Similarly, Emerald and Amethyst were developed for the winter growing area of Arizona. These cultivars not only provide buds of more uniform quality, but the plants are easily vernalized.

Present outlook. In 1985 , I became interested in the annual culture of globe artichokes after noting that $40 \%$ of California's crop was shipped to regional markets in New York and Boston (Anon 1985). In 1998, fully 5,250 tons of artichokes were shipped to these same East Coast markets (Anon 2000). Following earlier reports on the annual culture of globe artichokes (Hill 1987, 1992, and Hill and Maynard 1989), keen interest was expressed by several commercial growers and numerous home gardeners. Connecticut-grown artichokes are seasonally offered at some roadside stands and farmer's markets, others are grown for specialty food store and restaurant accounts.

In this bulletin. I evaluate new annual cultivars that can be grown with natural vernalization (cool spring temperatures in a cold frame) and compare them with older cultivars that require induced vernalization (controlled cool moist temperatures in a refrigerator). Plants with induced and natural vemalization were evaluated for yield, bud weight, quality, and harvest duration.

\section{SOILS, RAINFALL, AND CUMULATIVE 50F TEMPERATURE}

Soils. The globe artichoke trials $(1998,2000)$ were conducted at Lockwood Farm, Mt. Carmel (Hamden) on Cheshire fine sandy loam, a well-drained upland soil with moderate moisture holding capacity. This soil has no compacted subsoil layers to restrict the growth of the artichoke plant's prominent tap root.

Rainfall. Rainfall distribution throughont the growing season (April-October) for 1998 and 2000 is shown in Table 1. Rainfall in each column represents the departure 
from the 30-year average inontlly rainfall for Mt. Canmel reported by the National Weather Service. Total rainfall during the 1998 and 2000 growing seasons was 33.9 and 32.7 inches, respectively, compared to a 30 -year average of 25.0 inches. Althoughs total rainfall during the 1998 growing season was nearly 9.0 inches above normal, deficits of 2.2 and 1.8 inches occurred in July and September, respectively.

Table 1. Departure from normal rainfall (inches) during the 1998 and 2000 growing seasons (April - October) at Mt. Carmel.

$\begin{array}{lccc} & \text { 30-Year } & & \\ & \text { Average } & 1998 & 2000 \\ \text { April } & 4.0 & 1.2 & 1.5 \\ \text { May } & 3.7 & 2.3 & 0.8 \\ \text { June } & 2.5 & 7.5 & 4.3 \\ \text { July } & 3.2 & -2.2 & 4.7 \\ \text { August } & 3.9 & 2.0 & 0.4 \\ \text { September } & 4.2 & -1.3 & 0.2 \\ \text { October } & 3.3 & 0.2 & -2.5\end{array}$

In 2000, rainfall throughout the growing season was 7.7 inches above normal with 24.8 inches falling between April and July. Despite deficits in August and October, the 2000 growing season was characterized by abundant water for excellent growth and yields. A drip irrigation system was installed in 2000 following the severe drought of 1999 which severely stunted the plants and drastically curtailed yields. The new system, however, was not needed.

Cumulative $50 F$ temperature. In 1998, there were 319 cumulative hours with ambient temperatures below 50F between April 10 (seedlings placed in a cold frame) and May 5 (seedlings planted in the field). In 2000, whose spring was abnormally cool, there were 618 cumulative hours with ambient temperatures below 50F between April 7 and May 17. In addition, there were 238 cumulative hours with temiperatures below $50 \mathrm{~F}$ near the end of the harvest season, between September 25 and October 16.

\section{METHODS AND MATERIALS}

Cultivars. In 1998, the only cultivar tested was Imperial Star, a cultivar designed for annual culture from seed and features low vernalization requirements to trigger bud formation (estimated to be less than 250 cumulative liours below 50F). In 2000, two cultivars with similar low vernalization requirements, Enerald and Ametlyst, were added. For comparison Green Globe and Green Globe lmproved, used in earlier trials (Hill 1987, 1993, Hill and Maynard 1989), were grown to determine their production in plants with natural vernalization. These cultivars are thought to be similar to those that require at least 500 hours of temperatures below 50F for vernalization. (Basnizki 1985).

Vernalization procedure. Vernalization is the metabolic process that causes a plant to cliange from a vegetative stage to a reproductive stage. This cliange may be induced by subjecting the germinating seed or growing plant to a cool, moist treatment. In 1998. germinating seeds and seedlings of Imperial Star were treated to two different levels of cold treatments, "induced" and "natural". Pertinent dates for vernalization, hardening and planting are listed in Table 2. lnduced vernalization was initiated February 8 . After soaking the seed in tap water at room temperature for tivo days to soften the seed coat, they were packed in moist unshredded sphagnum moss in an unsealed one-gallon plastic bag and refrigerated for four weeks at $36-40 \mathrm{~F}$. The seeds were exanined weekly and moistened, if necessary. In early March, four-week-old gerninated seed with roots extending $1 / 4$ to $3 / 4$ incl were transferred to 1 -quart black plastic containers filled with Promix BX and placed, closely packed, in a greenhouse maintained at 50-75F. If temperatures exceeded 85 during the day, the seedlings were sprayed with cold water early in the afternoon to prevent devernalization (Hanvood and Markarian 1968). Perimeter containers, fully exposed to sunlight, were draped with aluminum foil to prevent excessive heat absorption through the wall of the black container. About $20 \%$ extra seedlings were grown to allow culling of weak plants as they were transplanted in the field.

Seedlings in the 4-leaf stage were transferred to a cold frame for hardening. Seedlings were covered at night only on the threat of frost. Uncovered seedlings were inadvertently subjected to night temperatures as low as $29 \mathrm{~F}$ without apparent injury.

Natural vernalization began on March 6. As before, presoaked seeds were placed in an unsealed one-gallon plastic bag filled with unshredded sphagnum moss, but left at room temperature (65-70F). After 10 days, germinated seeds were planted in one-quart pots and placed in a greenlouse until the first true leaves began to form. In early April, they were transferred to a cold frame for early growth and vernalization until they were ready for transplanting at the 4-leaf stage.

Fertilization. Soluble 20-20-20 fertilizer (1 tbsp/gal) was added to the potted seedlings about 10 days before transplanting. The field soil was fertilized with 10-10-10 at a rate of $1300 \mathrm{lb} / \mathrm{A}$ before transplanting. The $\mathrm{pH}$ of the soil was 6.5 and did not require liming.

Field transplanting. 1n 1998, seedlings with induced vernalization were transplanted in early May: those with natural vernalization in early June (Table 2). $\ln 2000$, seedlings with natural vernalization were transplanted in early May when they lad reached the 4-leaf stage.

All transplants were spaced two feet apart in rows four feet apart, a plant density of 5,445 plants/A. The holes for the transplants were sufficiently deep to accommodate the tap root that usually coiled at the botton of the pot. In 1998 . two 50-foot rows each of seedlings with induced and natural 
Table 2. Pertinent dates for vernalizing, hardening, and transplanting antichoke seedlings - Mt, Canmel, 1998, 2000.

Activity 1998

2000

Induced vernalization

Vernalized germination seed in refrigeration

Plants in pots in greenhouse

Transfer to cold frame for lardening

Transplant in ficld

\author{
Febniary 8 \\ March 4 \\ April 10 \\ May 5
}

Natural venalization

Germinate seed at room temperature

Plant in pots in greenlıouse

Transfer to cold frame for vemalization

Transplant in ficld

$\begin{array}{ll}\text { March 6 } & \text { Marcl 3-13 } \\ \text { March 16 } & \text { March 10-20 } \\ \text { April 28 } & \text { April 7-11 } \\ \text { June 2 } & \text { May 18 }\end{array}$

vernalization were planted ( 50 plants each).

In 2000, the five artichoke cultivars were planted in five 6()-foot rows with similar plant spacing ( $2 X+$ fect). Each cultivar was randomly planted in each of the fire replicated rows. Each replication contained five plants of cach cultivar. a total of 25 plants/cultivar.

Mulching. Summer heat may cause devernalization of unprotected plants. Immediately after transplanting. the soil was cooled with four inches of undecomposed leaf mulch. Although it was necessary to mulch only within 12 inches around the plant, the remaining space between the rows wals mulched to control weeds.

Irrigation. In 1998. the crop was irrigated twice in July to maintain an adequate supply of water. $\ln 20(0)$, no irrigation was necessary througliout the growing scason.

Gibberellic acid treatment. Gibberellic acid (GA3) is a uatural plant hormone found in most licrbaceous plants. lis use in artichoke culture initiates bud formation and speeds their development in barren plants (Gerakis et al. 1962). Its use to promote budding in cultivars that require long exposure to low temperature requirements for vernalization assured development of buds in 8()$-85 \%$ of plants. especially in years with limited spring rainfall (Hill and Maynard 1998). On July 15. 1998. all barren plants with induced vernalization that liad failed to form buds ( 6 of 50 plants) were sprayed with 5) ppm GA3, directed to the center of the plant strrounding the growing tip. On Atrgust 19.1998, 17 of 5) plants with natural remalization remained barren and were similarly spray'ed with 50 ppm GA3.

ln 2000 , all barren plants (22 of 125) in mid-August remained untreated to determine whether they would eventually produce buds as fall temperatures cooled.

Harvest. The buds were harrested at 7-10-daly intervals before the lower bracts began to spread. Artichokes weighing less than 2.5 ounces were discarded. These discards were smaller than the 60 ) size class (60) buds/standard box), the smallest commercial grade.

\section{YIELD OF BUDS}

In 1998, plants with induced vernalization produced 2.4 buds/plant compared to 3.9 buds/plant with natural icrnalization (Table 3). Han'est of buds on plants with induced vernalization began about three weeks earlicr than plants with natural vernalization, a consequence of earlier planting. The plants with induced vernalization were not as large as those with natural vemalization at the time of first harvest. The main stem of plants witl induced vernalization displayed little branching. Plants with one primary artichoke and two secondary artichokes were most common. ln plants witl natural vernalization. the main stem was thicker and produced additional smaller artichokes at leaf axils along the main stem. Many of these tertiary buds reaclied marketable size. There was little difference in the average bud weight from plants grown with cither vernalization technique. Three of 50 plants that produced their buds early in July produced a second crop of marketable buds in October from basal sprouts that dereloped after the main stem withered. This is consistent with earlier observations (Hill 1987) with the cultivar Green Globe.

Table 3. Yicld of Imperial Star buds from plants with induced vernalization vs. natural venalization at Mt. Carmel 1998

$\begin{array}{lcccc} & \text { Plants } & \text { Buds/ } & \text { Wt./ } & \text { Total } \\ \text { Producing } & \text { Plant } & \text { Bud } & \text { Yield* } \\ & \% & \text { No. } & \text { Oz } & \text { No. buds/A } \\ \text { lnduced vernalization } & 92 & 2.4 & 5.5 & 12.020 \\ \text { Natural vernalization } & 90 & 3.9 & 5.7 & 19.110 \\ \text { * Bascd on 5+45 plants/A (2X+ foot spacing) X buds/plant } \\ \text { \% plants producing }\end{array}$

Plants with natural vernalization produced an estimated 19.(10) buds/A compared to 12.000 buds/A for plants with induced vernalization (Table 3). 
In 2000, all naturally vernalized cultivars responded well to the benefits of an extended period of cool. moist weather in spring. Among all cultivars. Green Globe had the greatest number of buds/plant (5.7), followed by lmperial Star (Table 4). Emerald had the fewest buds/plant, but their average weight was greatest ( 6.5 ounces/bud). The arerage weight/bud of Imperial Star and Amethyst was equal to or greater than 6.0 ounces. Grecn Globe had fewer plants producing buds than all other cultivars. All Green Globe plants that remained barren at the end of the growing scason were stunted despite rigorous culling during planting. The productive plants of Green Globe were larger than average with multiple branching of the main stem. Many tertiary buds developed at the leaf axils. Trio individual plants produced nine marketable buds. These plants were fully two feet taller than other plants in the trial. illustrating the diversity of Green Globe planted from seed. Total estimated vield of Imperial Star, and Green Globe exceeded 25.t)(x) buds/A. Although the total estimated yield of Amethyst cxcecded 20.0000 buds/A, $25 \%$ of the plants produced malformed buds. It is unknown whether the defect was a physiological disorder or a genetic abnormality. No other cultivars produced malformed buds.

Table 4. Yield of articlıoke buds from plants with natural vernalization at Mt. Carmel. 2000.

$\begin{array}{lcccc} & & & & \text { Total } \\ & \text { Plints } & \text { Buds/ } & \text { WV } & \text { Yicld } \\ \text { Producing } & \text { Plant } & \text { Bud } & \text { Buds* } \\ \text { Cultivar } & \% & \text { No. } & \text { Oz } & \text { No/A } \\ \text { lmperial Star } & 100 & 5.0 & 6.1 & 27.225 \\ \text { Emcrald } & 96 & 3.8 & 6.5 & 19.865 \\ \text { Amethyst } & 92 & 4.1 & 6.0 & 20.540 \\ \text { Green Globe } & 72 & 5.7 & 5.6 & 22.345 \\ \text { Green Globe linp. } & 100 & 4.6 & 5.8 & 25.045\end{array}$

* Based on $5+45$ plants/A ( $2 x+$-foot spacing) $x$ buds/plant $x$ $\%$ plants producing

\section{HARVEST SPAN}

In 1998. the first buds from plants with induced vernalization were harvested on July 17. Buds from plants with natural vernalization were first harvested on August 6 . abont three weeks later. All harvests concluded November 4 . a harrest span of 15.7 wecks for plants with induced vernalization and 12.8 weeks for plants with matural vernalization. Despite the long harvest span of plants with induced vernalization. fully $86 \%$ of the buds were harnested between July 17 and August 27, a 5.9-week span. The remaining 14\% were larested between September 9 and November 4. mostly from barren plants that lad been treated with GA3 on August 19.

In $20(0)$, larest from all naturally vernalized plants began on July 28 and ended on November 18 , a span of 16.1 wecks. Buds laarvested after October 23 were "rrost kissed" a tcrm used in the artichoke industry to describe buds ivhose thin, wayy cuticle had been nuptured by frost. This condition is a cosmetic defect and does not affect the taste of the articlioke.

\section{GIBBERELLIC ACID TREATMENT OF BARREN PLANTS}

In 1998. GA3 treatment of barren plants in mid-August initiated bud formation in two of six plants with induced vernalization and 12 of 17 barren plants with natural vernalization (Table 5).

Table 5. Treatment of barren articlioke plants on August 19 with GA3 (1998) or left untreated (2000).

\begin{tabular}{|c|c|c|c|}
\hline & $\begin{array}{c}\text { Barren } \\
\text { No. }\end{array}$ & $\begin{array}{c}\text { Barren } \\
\text { No. }\end{array}$ & $\%$ of \\
\hline 1998-Trcated & August 18 & Sept. 24 & Plants \\
\hline Induced vernalization & 6 & 4 & 8 \\
\hline Natural venalization & 17 & 5 & 10) \\
\hline & $\begin{array}{c}\text { Barren } \\
\text { No. }\end{array}$ & $\begin{array}{c}\text { Barren } \\
\text { No. }\end{array}$ & $\%$ of \\
\hline $200(0$-Untreated & Augusi 24 & October 23 & Plants \\
\hline Amethyst & 6 & 2 & 8 \\
\hline Emerald & 3 & $1^{*}$ & 4 \\
\hline linperial Star & 2 & () & () \\
\hline Green Globe & 7 & 7 & 28 \\
\hline Green Globe Imp. & 2 & 0 & 0 \\
\hline
\end{tabular}

* Bud formed but too late to attain marketable size.

If untreated. would these barren plants eventually produce buds if vernalization was dekyed until fall when cooler temperatures prevailed? In 2000), 2-7 plants of each cultivar were barren on August 24. By October 23, most of these plants had produced buds without GA3 treatment. The notable exception was Green Globe. whose seven barren plants did not respond to cool fall temperatures. Despite being exposed to 618 hours of temperatures below $50 \mathrm{~F}$ during spring, these plants never produced buds. These plants were stunted and probably would not have borne marketable buds even if they had developed.

\section{MANAGEMENT STRATEGIES}

('ultivar selection. There are limited cultivars available for use in annual production from seed. Imperial Star and Emerald produce attractive buds for relail sale. The buds of Impcrial Star are thomless, glossy and grayish-green in color (Schrader and Mayberry 1992). The bracts are slow to 


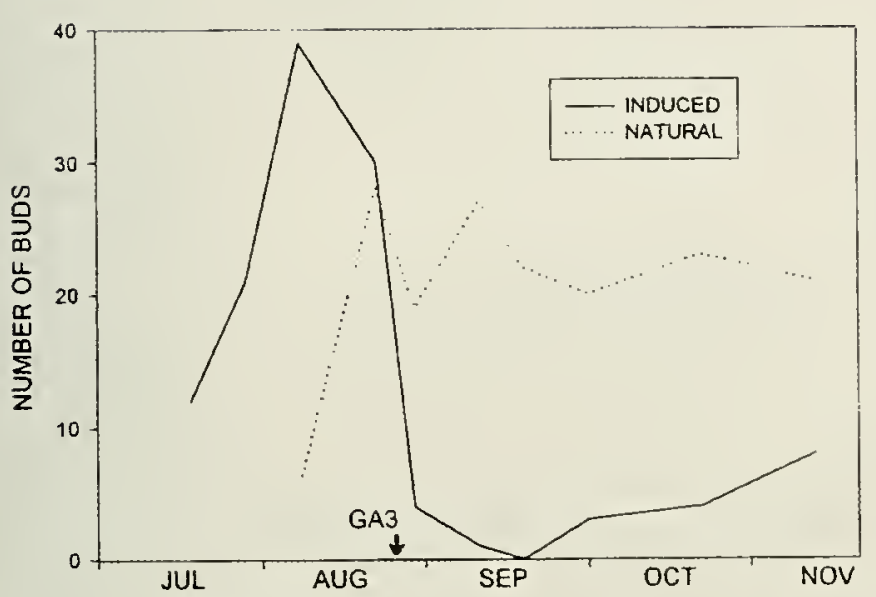

Figure 1. Distribution of artichokes throughout the growing season from plants with induced and natural vemalization. 1998.

spread, an advantage if liarvests are delayced. The buds of Emerald are more elongated than Impcrial Star. Their glossy, green bracts are large and meaty and their hearts are large. Although the number of buds/plaut was lower than other cultivars, the plants produced a larger percentage of buds in the 24-36 size grades.

Green Globe and Green Globe lmproved wcre also selected for annual culture. Both are reliable cultivars but some buds are thomy. In earlier trials, both responded well to induced vernalization. In 2000, when spring icmpcralurcs were unusually cool, natural vernalization of all cultivars assured above-normal yiclds.

Gibberellic acid treatment? In earlier trials. treitment of barren plants in late July through early August was beneficial only to Green Globe, which required extended low temperatures (less than 50F) for vernali/ation. Birren plants of cultivars that require fewer hours of cold temperature (Imperial Star, Emerald, and Amcthyss) eventually produced buds as fall temperatures lowercd.

l ernalization: induced or natural'? There are sercral adrantages of matural vemalization that begins in March The necd for grecuhouse space is avoided. which results in a sill inges in produclion costs. For commercial growcrs or honk sardencrs. matual remalizalion permits hanest of

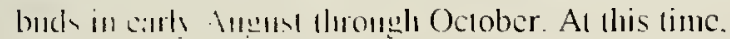

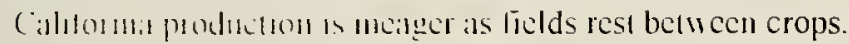

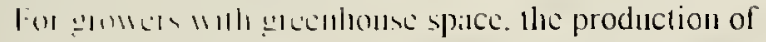

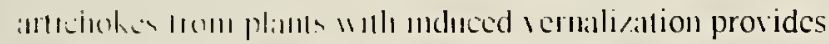

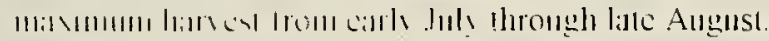

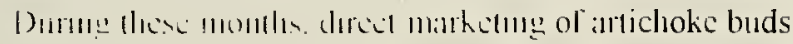

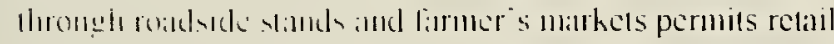

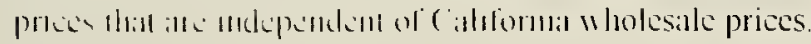

Growers may wish to consider producing two artichoke crops, one grown from plants with induced vernalization and onc grown from plants with natural vernalization. Figure 1 illustrates that early production in mid-July through late August from plants with induced vernalization is replaced by production from plants with natural vernalization. Although production from plants with induced vernalization drops sharply in late August, additional production in September and October stcms from barren plants that were treated with gibbcrellic acid in August and also from plants that died back and re-sprouted to produce a second crop.

Conncclicut growers who liave produced articliokes from sced report that the advantages of freshness and taste appeal bring customcrs back for repeat sales

\section{REFERENCES.}

Anon. 1985. Agricultural statistics-1985. USDA. 551p.

Anon. 2000. Agricultural statistics-2000. USDA. IV 30-31.

Basnizki. Y. 1985. Cunara scolvmus. In CRC Handbook of Flowcring. Vol. 11. Halery, A.H. Ed. 391-9 CRC Press. Boca Raton. FL.

Haniood. R.R. and Markarian. D. 1968. Annual culture of globe artichokes (C.mara scolvmus L.). 1. Preliminary report. Proc. Amer. Soc. Hort. Sci. 92: 4(0)-9.

Gerikis. P.A. Markarian. D. and Honma, S. 1969. Vernalization of globe articlıokes (C vnara scolvmus L.). J. Amer. Soc. Hort. Sci. 94:254-8.

Hill. D.E. 1987. Globe artichokes in Connecticut. Conn. Agr. Exp. Sta. Bull. 846. 9p.

Hill. D.E. 1993. Anmual culture of globe artichokes. mulching and planting datc trials 1989-1992. Conn. Agr. Exp. Sta. Bull. 911. 8p.

Hill. D.E.. and Maynard, A.A. 1989. Globe artichoke trials 1987-1988. Comm. Agr. Exp. Sia. Bull. 867. 9p.

Ry.der. E.J.. DcVos. N.E.. and Bari. M.A. 1983. The globe artichoke (C yara scolvmus L.). Hort. Sci. $18: 6+6-53$.

Schrader. W.L., and Mayberry, K.S. 1992. 'Imperial Star' articlıoke. Hort. Sci. 27:375-6.

Splillslocsscr. W.E. 1979. Vegctablc Growing Handbook. AVI Publishing Company. Wcstport. CT. 289p.

Yamaguchi. M. 1983. World Vegelables: Principles, Production. and Nutritive Value. AVI Publislung Compan!. Wcstpon. CT. 415 p. 


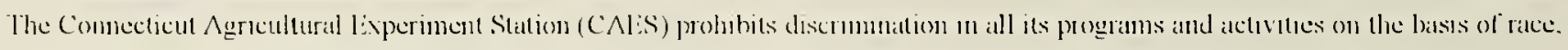

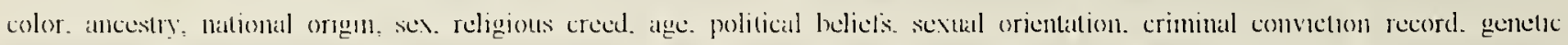
information. learning disability. present or pist history of mental disorder. mental retardation or physical disibility including hut not limited o blindness, or marital or lamily status. To lile a complaint of discrimination. write Director, The Conneclicul $\wedge$ gricultural

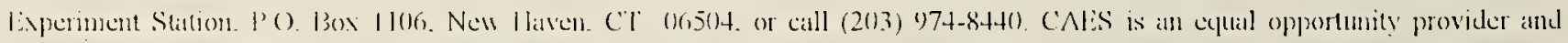

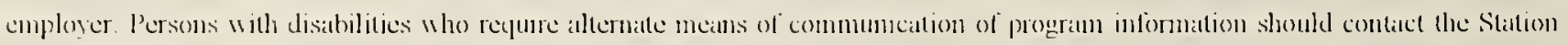

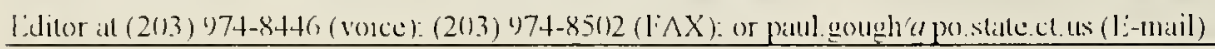




\title{
th University of Connecticut Libraries
}

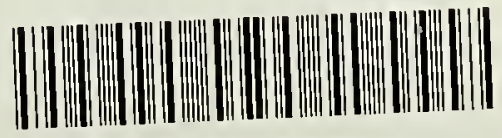 \\ $\mathbf{3 9 1 5 3 0 2 9 3 2 8 0 2 0}$
}




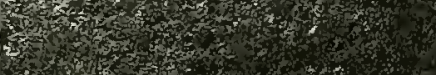

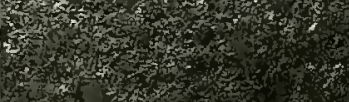

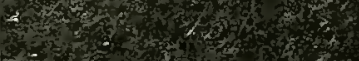

